\title{
Keiserens sønn
}

Av og til oppstår strid om viktige ansettelser. Det skjedde også i 1909, da en rekke innlegg i Tidsskriftet handlet om hvem som skulle bli professor i propedeutisk kirurgi. Det hadde meldt seg fire søkere: Otto Borchgrevink (1856-1928), Peter Bull (1869-1951), Johan Nicolaysen (1860-1944) og Kristian Jervell (1859-1921). Etter at den sakkyndige komiteen hadde uttalt seg, var det fremdeles en viss tvil om hvem som burde foretrekkes. Et mindretall i fakultetet stemte for ytterligere konkurranse for å teste søkernes egenskaper som lærere. I en redaksjonell artikkel i Tidsskriftet støttet man sterkt dette synet (1909; 29: 147-9). Til liten nytte, viste det seg. Nicolaysen trakk det lengste strået. Også hans far, Julius Nicolaysen (1831-1909), hadde vært kirurgiprofessor, kjent under navnet Keiseren.

\section{Professorposten i propædeutisk kirurgi.}

Under disse forhold maa vi meget beklage, at saken i fakultetet har faat det utfald, som nu foreligger. Besættelsen av et professorat i kirurgi er nemlig av saa stor betydning for vor lægestands forsvarlige utdannelse, og for faget selv, at en saa sjelden begivenhet i vor hjemlige medicin - den hænder knapt 2 gange i en menneskealder - absolut kræver, at besættelsen kun sker efter den mest omhyggelige overveielse og omfattende konkurrence i alle henseender. Det veier heller ikke litet, at lærerstillingens besættelse er en velfærdssak saavel for den ansøker, som ansættes, som for de andre, som ikke blir ansat.

Saa usikkert som resultatet av de sakkyndiges erklæringer er, forekommer det os, at disse hensyn ikke er skedd tilstrækkelig fyldest, og at fakultetets indstilling synes noget vilkaarlig. Vi henstiller derfor indstændig til kirkedepartementet, at der foreskrives en yderligere konkurrenceprøve for særlig at bringe de kvalificerte ansøkeres duelighet som docenter paa det rene. 